MAREK WOŹNIAK

\title{
BIOGRAFISTYKA - „HISTORIA Z LUDZKĄ TWARZĄ”?
}

Biografistyka we współczesnych badaniach historycznych. Teoria i praktyka, red. Jolanta Kolbuszewska, Rafał Stobiecki, Łódź: Wydawnictwo Uniwersytetu Łódzkiego 2017, ss. 228.

DOI: http://dx.doi.org/10.18290/rh.20681-13

Przyjęcie założenia, według którego nasz, ludzki sposób „doświadczania świata", przez fakt jego kulturowego i społecznego usytuowania, zgodnego

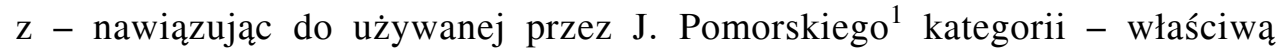
danej wspólnocie matryca kulturową, pozwala patrzeć na te same doświadczenia nie tylko jako odmiennie doświadczane i utrwalane, ale sugeruje jednocześnie, że historiografia poznawczo jest szczególnego rodzaju metadoświadczeniem: „interpretacją [...] czyjegoś doświadczania świata”, opisem tego, jak „współcześni radzili sobie poznawczo z własna przeszłością, jest zapisem ich subiektywno-społecznego doświadczania świata”. W konsekwencji można uznać - i tak czyni Pomorski - że historiografia jest nie tyle źródłem poznania odmiennych od historyka kultur (badanych), ile źródłem do poznania samej kultury poznającej². Idąc dalej w tym duchu, uznać można - lub jedy-

Dr hab. MAREK WOŹNIAK, prof. UMCS - Wydział Nauk Humanistycznych, Uniwersytet Marii Curie-Skłodowskiejw Lublinie; e-mail: m.wozniak@ poczta.umcs.lublin.pl

${ }^{1}$ J. POMORSKI, Historiografia jako autorefleksja kultury poznajacej, w: Świat historii, red. W. Wrzosek, Poznań 1998.

2 Tamże, s. 375-377; por. M. WoŹNIAK, Doświadczanie historii, Lublin 2002, s. 63-64. W innym artykule Pomorski dodaje: „Historiografia może być interpretowana jako proces komunikowania naszego doświadczania świata" (J. POMORSKI, Czy scjentyzm w historiografii końca XX wieku jest catkiem passe?, „Historyka” 30(2000), s. 23).

ROCZNIKI HUMANISTYCZNE 68:2020 z. 1 
nie na chwilę założyć - że „historia nic nie mówi nam o przeszłej rzeczywistości, ona mówi zwyczajnie, jak ludzie doświadczają tej rzeczywistości"3. Pytanie, moim zdaniem ze swej natury mające charakter retoryczny, czy te same uwarunkowania/cechy nie definiują tego rodzaju gatunku pisarstwa historycznego, któremu nadajemy etykietę biografistyki, a zatem czy w konsekwencji przyjętego wcześniej założenia, nie jest także w tym przypadku tak, że w momencie doświadczania czegoś innego (konstytuowania opisów doświadczeń ludzi z przeszłości) nie odnosimy ich do własnych doświadczeń. Czy podobnie jak historiografia, okazuje się dla niektórych (auto)refleksja kultury poznającej - zapisem tego, w jaki sposób w jej ramach doświadczamy przeszłość - tak biografistyka w takim samym (co najmniej) stopniu co o swoich bohaterach nie mówi o Autorach biografii - czy szerzej: o nas samych. W podobny bowiem sposób ujawnia nasze (kulturowo uwarunkowane) oczekiwania, punkty widzenia, pragnienia, pytania i odpowiedzi, które są dla nas (naszej kultury) ważne, istotne, pożądane. I być może z tego właśnie powodu biografistyka pozostaje wciąż niezwykle ważną częścią badań historycznych.

Patrząc na dzieje historiografii nietrudno również dostrzec, że mimo wszelkich zmian - tak w samym stosunku do przeszłości, jak i w obszarze przedmiotu zainteresowań/badań, celów stawianych przed historykami/dziejopisami, źródeł wiedzy o przeszłości, narzędzi i metod badawczych czy wreszcie strategii i form narracyjnych ${ }^{4}$ - jakie możemy zaobserwować na przestrzeni wieków na gruncie pisarstwa historycznego, jedno (co najmniej) pozostaje niezmienne. Od samych jej początków, po dziś dzień, historycy bohaterem swoich opowieści czynią człowieka. Heroiczne i godne upamiętnienia czyny władców, bogów, herosów, żywoty świętych, traktowane jako matryce wszelkich cnót i postaw właściwych człowiekowi oraz wzorów do naśladowania, od zarania ludzkiej aktywności zmierzającej do przywoływania tego, co było, najmocniej obecne były (i są) w tej formie aktywności związanej z odwoływaniem się do przeszłości, którą współcześnie określamy mianem biografistyki. I choć przedmiotem zainteresowań historyków (i czytelników) nie są już jedynie przedstawiciele szeroko rozumianych elit - co w pewnym sensie jest najpełniejszym ucieleśnieniem słów Woltera: „Mamy prawie wyłącznie historię królów, ja chcę historii ludzi" - to nie zmienia to faktu, że właśnie (indy-

\footnotetext{
3 J. POMORSKI, Czy scjentyzm, s. 20-22.

${ }^{4}$ Do dziś najważniejszymi w opisie i eksplantacji tych zmian pozostają w moim przekonaniu prace K. Pomiana: Przeszłość jako przedmiot wiary. Historia i filozofia w myśli średniowiecza (Warszawa 1968) oraz Przeszłość jako przedmiot wiedzy (Warszawa 1992).
} 
widualne) biografie (stale i niezmiennie) od stuleci stanowią istotną część dorobku historiografii.

Dostrzegli to również redaktorzy niezwykle interesującej pracy zbiorowej Biografistyka we wspótczesnych badaniach historycznych ${ }^{5}$ - J. Kolbuszewska oraz R. Stobiecki - którzy już we Wstępie, odpowiadając na pytanie o to, czym jest historia? wyjaśniają, że jest to ,nauka o ludziach w czasie. W najogólniejszym sensie to ludzie tworzą historię, jest ona domeną działań jednostek o odróżnialnych cechach, odmiennych życiorysach, reprezentujących różne systemy wartości i doświadczenia"6. I trudno się z taką, jak sądzę, powszechnie akceptowaną intuicją nie zgodzić, szczególnie zważywszy na fakt niesłabnącej - tak z punktu widzenia zainteresowań badaczy, jak i, a może przede wszystkim potrzeb czytelników - popularności biografistyki. Nie da się bowiem ukryć, iż dzieje jednostki - niezależnie od tego, czy (jak to miało/ma miejsce w klasycznej wizji historiografii) sa to losy „wielkich” kreatorów dziejów (władców, wodzów, przedstawicieli elit), czy jedynie „Zwykłych” ludzi (jak to występuje w mikrohistoriach, historiach życia codziennego czy tzw. historiach mniejszości) - pozostają ciągle jednym z dominujących, nie tylko w sensie ilościowym, przedmiotów zainteresowań historyków ${ }^{7}$. Co więcej, z punktu widzenia zainteresowanych praktyką badawczą historyków, wartość publikacji wzrasta, jeśli za Redaktorami uwzględnimy fakt, że zmiany, które możemy obserwować we współczesnej biografistyce, są pochodną zmian (,,w sposobach rozumienia i uprawiania historii”) zachodzących w całej historiografii. Jak bowiem słusznie zauważaja Redaktorzy: „W przestrzeni publicznej funkcjonują obok siebie różne rodzaje ujęć biograficznych w postaci «biografii klasycznych», «biografii teoretyzujących», w których autor odwołuje się do zastanej teorii, np. psychologicznej, oraz «biografie literackie», gdzie relacje między naukowością a literackością pozostają ze sobą w swoistym sprzężeniu zwrotnym. Nowym zjawiskiem są biografie rzeczy" ${ }^{\prime \prime}$. Dla nikogo nie powinno być tajemnicą, iż scharakteryzowany

\footnotetext{
${ }^{5}$ Biografistyka we wspótczesnych badaniach historycznych, red. J. Kolbuszewska, R. Stobiecki, Łódź 2017.

${ }^{6}$ Tamże, s. 7.

${ }^{7}$ Choć przecież nie tylko....; redaktorzy tomu obok pluralizacji (,,pojawienie się różnych, często nieprzystających do siebie opowieści o historii”) oraz dezintegracji (,rozpad powszechnie akceptowanego wzorca uprawiania historii oddziedziczonego po XIX stuleciu"), słusznie wskazują demokratyzację historii (,,we współczesnym świecie każdy może być historykiem, ma prawo do własnej historii”) jako uzasadnienie dla swojej publikacji, zob. tamże, s. 8.

${ }^{8}$ Tamże, s. 8.
} 
w ten sposób dorobek i stan współczesnej biografistyki - nieco upraszczając problem/zjawisko - jest, a przynajmniej może być za taki uznany, właściwy dla całej historiografii.

Wymienione wyżej powody sprawiają, że nie powinien budzić żadnych wątpliwości fakt, że praca, której Redaktorami są znakomici historycy historiografii z Łodzi, jest niezwykle ważną i cenną publikacją. W tym kontekście podkreślić należy już na wstępie, że recenzowana publikacja wychodzi naprzeciw zapotrzebowaniu - znane (niezbyt liczne zresztą) prace z zakresu szeroko rozumianej teoretyczno-metodologicznej refleksji nad biografia/biografistyką ${ }^{9}$ z pewnością nie mogły (i nie mogą) w żaden sposób zaspokoić tych potrzeb - na tego typu refleksję, jaka stała się udziałem Autorów poszczególnych tekstów. Popularność, tak w wymiarze czytelnictwa, jak i, a może przede wszystkim, w wymiarze uprawiania biografistyki, powiązanie z kondycją współczesnej historiografii, a także jej niesłabnąca obecność w dyskursie publicznym, od dawna domagały się uwzględnienia w literaturze oraz poddania refleksji naukowej tych jej właściwości, które we wcześniejszych publikacjach (mam tu na myśli przede wszystkim prace G. Zalejki ${ }^{10}$, ale także te późniejsze sygnowane nazwiskami A. Całki ${ }^{11}$, W. Durki ${ }^{12}$, W. Zajewskiego ${ }^{13}$, E. Skibińskiej ${ }^{14}$, K. Polasik-Wrzosek ${ }^{15}$ czy wreszcie Autorów hasła Biografia w niezwykle cennej pracy pod redakcją M. Saryusz-

9 Zaliczyłbym do nich przede wszystkim prace zbiorowe, a wśród nich: O biografii i metodzie biograficznej, red. T. Rzepa, J. Leoński, Poznań 1993; Stan i perspektywy rozwoju biografistyki polskiej, red. L. Kuberski, Opole 1998; Biografia i historiografia dawniej i dziś, red. R. Kasperowicz i E. Wolicka, Lublin 2005; Biografie naukowe. Perspektywa transdyscyplinarna, red. M. Kafar, Łódź 2011; Badanie biografii - źródta, metody, konteksty, red. R. Skrzyniarz, E. Krzewska, W. Zgłobicka-Gierut, Lublin 2014.

${ }^{10}$ Patrz między innymi: G. ZALEJKO, Biografistyka historyczna - zarys ewolucji gatunku, „Historyka” 18(1988), s. 37-55; TENŻE, Z metodologicznych zagadnień biografistyki historycznej, „Przegląd Humanistyczny” 1989, nr 8-9, s. 129-141; TENŻE, Przeciw metodzie (biograficznej). Refleksje nad historycznościa biografistyki, w: O biografii i metodzie biograficznej, red. T. Rzepa, J. Leoński, Poznań 1993, s. 15-24.

11 A. CAŁEK, Biografia naukowa: od koncepcji do narracji. Interdyscyplinarność, teorie, metody badawcze, Kraków 2013.

${ }^{12}$ W. DuRKA, O biografii i metodzie biograficznej, „Studia Socjologiczne” 1995, nr 3-4.

${ }^{13}$ W. ZAJEWSKI, Biografistyka jako gatunek twórczości historiograficznej, „Czasy Nowożytne" 8(2000).

${ }^{14}$ E. SKIBIŃSKA, Badania biograficzne - dylematy metodologiczne (wybrane zagadnienia), „Studia Edukacyjne” 2008, nr 8, s. 77-86.

${ }^{15}$ K. POLASIK-WRZOSEK, Biografia jako gatunek $w$ domenie historii historiografii, ,Sensus Historiae". Studia interdyscyplinarne 2013, nr 3. 
Wolskiej oraz R. Traby ${ }^{16}$ ) nie były bądź były słabo obecne, zwłaszcza w teoretycznej i metodologicznej refleksji/namyśle nad biografistyką. W moim przekonaniu monografia ta nie tylko rozwija i uzupełnia dotychczasowy stan wiedzy, ale przede wszystkim podejmuje - w większości przypadków znakomicie - te wątki, które dotychczas nie stały się, mimo ciągle rosnących potrzeb $\mathrm{w}$ tym aspekcie, przedmiotem krytycznej refleksji nad uprawianiem badań z zakresu biografistyki, a szerzej: także przecież całego dziejopisarstwa. Wysoka kultura metodologiczna wszystkich Autorów (założenia, używane narzędzia badawcze, interdyscyplinarność, jasność wywodów, precyzja języka, wyraźnie określone cele, dookreślone przedmioty badań) sprawia, że w dotychczasowej literaturze przedmiotu trudno wskazać pozycję, która w podobnym/równym stopniu/wymiarze realizowałaby zapotrzebowanie płynące ze strony badaczy na tego typu wiedzę/refleksję. Tym bardziej należy podkreślić ogromną pracę włożoną w to niezwykle wartościowe dzieło oraz podziękować Redaktorom za to, że udało się namówić tak znakomitych badaczy (historyków, historyków historiografii, metodologów czy wreszcie teoretyków poznania historycznego), reprezentantów tak wielu i tak znaczących ośrodków akademickich i naukowych z Polski i z Ukrainy, do udziału w tym przedsięwzięciu.

$\mathrm{Na}$ recenzowaną pracę składa się 13 artykułów podzielonych na dwie części, poprzedzonych bardzo dobrym pod względem merytorycznym i formalnym Wstępem oraz zamieszczoną na końcu Bibliografią. Nie będę ukrywał, że wątpliwości budzi właśnie obecność - oddzielonej wyraźnie od poszczególnych tekstów i niejako sumującej wykorzystaną w nich literaturę Bibliografii. Z aktualnego Rozporządzenia Ministra Nauki i Szkolnictwa Wyższego z dnia 12 grudnia 2016 r. $^{17}$ wynika, że „monografie naukowe [...] zalicza się do osiagnięć naukowych”, jeżeli są „opatrzone właściwym aparatem naukowym (bibliografia lub przypisy)". Jako że nie ma obecnie formalnych powodów umieszczania oddzielnej bibliografii, sugerowałbym na przyszłość - choć oczywiście decyzję pozostawiam Redaktorom - zamieszczanie literatury przedmiotu po poszczególnych tekstach. Jest oczywiste, że choć Bibliografia stanowi istotne $\mathrm{z}$ różnych powodów uzupełnienie, a czasem wręcz rozszerzenie treści monografii, to jednak w zaproponowanej w tym przypadku (książka składa się z niejako autonomicznych artykułów) formule

\footnotetext{
${ }^{16}$ K. KAŹMIERSKA, P. CZAPLIŃSKI, V. JULKOWSKA, Biografia, w: Modi memorandi. Leksykon kultury pamięci, red. M. Saryusz-Wolska, R. Traba, Warszawa 2014, s. 61-67.

17 Rozporządzenie Ministra Nauki i Szkolnictwa Wyższego z dnia 12 grudnia 2016 r. [dostęp: 25.04.2018].
} 
efektywne korzystanie z jej zalet jest nieco utrudnione. Nie mam natomiast żadnych wątpliwości odnośnie do „kompletności” treści merytorycznych publikacji (jako całości).

Choć sam tytuł jest jak najbardziej adekwatny do treści publikacji, to już (niewielkie) wątpliwości budzą śródtytuły, przede wszystkim w kontekście nieco sztucznego, moim zdaniem, podziału na „teorię i praktykę”. Nie wchodząc w szczegóły odnośnie do treści poszczególnych artykułów, dla czytelnika wygląda trochę, jakby w części I (W kręgu teorii. Podstawowe kategorie, modele badawcze, dorobek) refleksje Autorów nie wynikały z praktyki badawczej, a nie da się ukryć, że w zasadzie wszyscy odwołują się - często wprost - właśnie do niej. W moim przekonaniu, teksty zamieszczone w części pierwszej są znakomitą refleksją (autorefleksją) badaczy-praktyków odwołujących się do własnych doświadczeń, tak z biografistyką, jak i szerzej $\mathrm{z}$ narracja stricte historyczną, a nie jedynie namysłem teoretycznym. W tym sensie, gdyby trzymać się zaproponowanego przez Redaktorów podziału, w części II (W kręgu praktyki dziejopisarskiej. Problemy, źródta, propozycje ujęć) powinny się znaleźć teksty o charakterze stricte biograficznym, a chyba - można powiedzieć na szczęście - tak nie jest. Wszystkie - może poza jednym - opracowania w zasadzie poprzedza dojrzały namysł o charakterze teoretycznym i metodologicznym, a w niektórych wątki te - jak w przypadku niezwykle interesującego tekstu Tomasza Toborka (,Wyklęci”, czyli kto? Biografistyka żotnierzy podziemia antykomunistycznego), czy równie ciekawego i wartościowego artykułu Andrzeja Czyżewskiego (Franciszek Zubrzycki „Maty Franek”- biografistyka w stużbie komunistycznej polityki pamięci) stanowią, jak sądzę, nie tylko integralny, ale i dominujący wątek rozważań. Nietrudno zauważyć, że tak jak w części I refleksja teoretyczna jest pokłosiem praktyki (dziejopisarskiej) Autorów, tak w części II praktyka dziejopisarska jest przede wszystkim konsekwencją namystu teoretycznego, obecnego - i co ważne: świadomie zwerbalizowanego - w treści poszczególnych artykułów. Przyznam, że osobiście miałbym duży kłopot z jednoznacznym przypisaniem poszczególnych tekstów do konkretnych części.

Publikacja ma charakter naukowy, żadnych wątpliwości nie budzi poprawność i logika wywodu w opracowaniach poszczególnych Autorów. Zaletą artykułów jest nie tylko wysoki poziom merytoryczny i warsztatowy, ale także odwołania do najnowszych publikacji i odniesienia do aktualnego stanu wiedzy na gruncie przedmiotu badań będącego obiektem ich refleksji. Nie mam żadnych uwag co do stylu, jasności przekazu czy adekwatności używanego przez poszczególnych Autorów języka do zaproponowanego przez Redaktorów rodzaju publikacji. Więcej: oprócz niewątpliwych wartości meryto- 
rycznych poszczególnych tekstów, a w konsekwencji także całej monografii, to właśnie styl i język, sposób prowadzenia narracji stanowią zaletę książki.

Treści poszczególnych artykułów znakomicie korespondują z zarysowanymi przez Redaktorów we Wstępie celami badawczymi i są, w moim przekonaniu, nierozerwalnie związane tak z refleksją teoretyczną, jak i praktyczną nad kondycją i zmianami dokonującymi się współcześnie na gruncie biografistyki (a szerzej: całej historiografii). Stawiane przez Autorów rozdziałów pytania oraz próby odpowiedzi na nie, formułowane problemy badawcze oraz wnioski sugerowane przez Autorów, z pewnością uzasadniają potrzebę ich szerokiej prezentacji. Jednocześnie wychodzą naprzeciw potrzebie, zapotrzebowaniu i oczekiwaniom historyków (ale przecież nie tylko) na namysł/refleksję nad - co już we Wstępie zostało podkreślone - „sposobami kreacji bohaterów” (np. artykuł M. Nowak czy W. Telwaka), strategiami „konstruowania narracji biograficznych" (np. teksty L. Zaszkilniaka, M. Solarskiej czy T. Pawelca), ich „typologią” (np. u V. Julkowskiej) oraz podstawą źródłową (np. teksty J. Maternickiego, L. Michalskiej-Brachy czy J. Kolbuszewskiej). Nakreślony „horyzont potrzeb i oczekiwań” (np. niezwykle interesujące teksty A. Wierzbickiego czy T. Pawelca), wskazanie odniesień do „polityki historycznej/pamięci” (jak u T. Toborka lub A. Czyżewskiego), czy wreszcie odwołania do „alternatywnych form przywoływania przeszłości” (jak np. w artykule P. Witka) sprawiają, że rozważania zawarte w monografii nie tylko charakteryzuje duża dawka oryginalności, ale także trudno znaleźć jakiś dający się łatwo uchwycić - tym bardziej w wydawnictwach zwartych - ich odpowiednik w dotychczasowej literaturze przedmiotu.

Zaletą publikacji (oraz poszczególnych tekstów) jest wysoka kultura metodologiczna wszystkich Autorów. Podziw budzi (samo)świadomość potrzeby ujawnienia przyjętych założeń oraz (auto)refleksja nad nimi. Najmniejszych wattpliwości nie budzą wykorzystywane narzędzia i procedury badawcze, czy zaplecze teoretyczne, do którego się odwołują. Jasność oraz precyzyjność używanego przez Autorów języka, dopełnione wyraźnie sprecyzowanymi celami badawczymi oraz poprawnie określonymi/skonceptualizowanymi przedmiotami ich zainteresowań, sprawiają, że nie tylko przekłada się to na wysoką jakość merytoryczną publikacji, ale jest jednocześnie budujące w konfrontacji z innymi publikacjami, podejmującymi się refleksji nad biografistyką jako taka, czy konkretnymi jej przejawami (biografie).

Wątpliwości nie budzi również poprawność formułowanych przez poszczególnych Autorów wniosków ani sposób ich prezentacji. W większości przypadków wnioski są wyprowadzane w sposób jasny, logiczny i przejrzysty, znajdują swoje uzasadnienie $\mathrm{w}$ założonej formie narracji oraz przyjętej strate- 
gii argumentacyjnej. W każdym przypadku mają wystarczające (choć czasem może nawet zbyt szerokie, jak w przypadku tekstu Strategie autobiograficzne $w$ historycznych filmach Andrzeja Wajdy. Zarys problematyki P. Witka ${ }^{18}$ ) uzasadnienie w materiale „dowodowym” (źródła, literatura przedmiotu). W jednym przypadku (tekst Jolanty Kolbuszewskiej - Potencjat informacyjny korespondencji matżeńskiej na przykładzie Leokadii z Mitraszewskich i Henryka Schmitta) warto było może nieco rozwinąć część (ostatni akapit), w której formułowane są wnioski, tak aby treść artykułu była bardziej adekwatna do tytułu ${ }^{19}$.

Przez wzgląd na podejmowaną problematykę oraz zaproponowaną przez Redaktorów i Autorów poszczególnych rozdziałów monografii perspektywę/y badawczą/e, w moim przekonaniu, książka stanowi nie tylko istotny wkład do stanu badań i refleksji nad biografistyką (uprawianiem biografistyki), ale także wpisuje się w szeroko rozumianą refleksję/debatę nad kształtem/kształtami badań z zakresu historii, historii historiografii czy metodologii historii. To właśnie zaproponowana perspektywa, jak sądzę, sprawia, że opracowanie zachęca do refleksji, także tej teoretycznej, nad rolą i zadaniami biografistyki/historiografii oraz alternatywnymi wobec klasycznego sposobami jej uprawiania, co daje dodatkowe argumenty w kontekście konieczności dotarcia z ustaleniami Autorów tekstów do szerszej publiczności, i to nie jedynie tej definiowanej jako społeczność akademicka (historyków, socjologów czy politologów), ale także kręgu potencjalnych autorów i czytelników biografii.

\footnotetext{
${ }^{18}$ Przede wszystkim z punktu widzenia z nie zawsze wprawionych, a często zwyczajnie nieprzygotowanych na tak wyrafinowane, a jednocześnie subtelne refleksje czytelników.

19 W tekście J. Kolbuszewskiej, moim zdaniem, lekki niedosyt budzi sama struktura, a przede wszystkim fakt, iż informacje biograficzne znalazły się przed zbyt mało wyraźnie wyodrębnionym wstępem. Sam wstęp do artykułu powinien natomiast nieco mocniej zarysować problematykę będącą przedmiotem zainteresowania Autorki, oraz jaśniej określić cele badawcze. Idealnym przykładem zastosowania takiej strategii formalnej jest następny tekst w tomie, a mianowicie (Auto)biograficzne konteksty badan nad listami polskiej emigracji we Francji w II połowie XIX wieku - spuścizna Józefa Gałezowskiego (1833-1916) L. Michalskiej-Brachy.
} 